\title{
前輪キャスター上げ動作が可能な車いすシミュレータの開発
}

\author{
坂東 直行 ${ }^{* 1}$, 近藤 学*2, 池田 貴公*3, 山田 宏尚 ${ }^{* 4}$
}

\section{Development of wheelchair simulator for training of wheelie motion}

\author{
Naoyuki BANDO*1 ${ }^{*}$, Manabu KONDO*2 ${ }^{*}$ Takahiro IKEDA*3 ${ }^{* 3}$ and Hironao YAMADA*4 \\ ${ }^{* 1}$ Industrial Technology and Support Division, Gifu Prefectural Government \\ 2-1-1 Yabuta-minami, Gifu, 500-8570, Japan \\ ${ }^{* 2}$ Seiko Epson Corporation, 3-3-5 Owa, Suwa-shi, Nagano 392-8502, Japan \\ ${ }^{* 3, * 4}$ Department of Mechanical Engineering, Gifu University \\ 1-1 Yanagido, Gifu 501-1193, Japan
}

Received: 12 March 2020; Revised: 23 May 2020; Accepted: 15 July 2020

\begin{abstract}
The purpose of this research is to develop a VR simulator that can safely train wheelie, which is a stepping technique for manual wheelchair users. The equation of motion of the wheelchair was shown, and the actual wheelchair motion was compared with the simulation results. A wheelchair simulator that moves using this equation of motion was constructed. The effectiveness of the simulator in wheelie training was evaluated by experiments. In the experiment, 20 subjects were divided into two groups of 10 subjects, and one group trained using a wheelchair simulator and did not practice the other group. After that, Subjects tried wheelie in a real wheelchair and we calculated the success rates. As a result, the average success rate of the group using the wheelchair simulator increased by about 48 points compared to the unused group. From the results, it was shown that the simulator developed in this study is effective for learning the wheelie motion.
\end{abstract}

Keywords : Virtual reality, Simulator, Wheelchair, Wheelie motion, Training

\section{1. はじめに}

車いすは介護・福祉機器の一つであり利便性が高く低コストであるため広く利用されている，しかし，車輪を 回転させて移動する乗り物であるため，車輪での移動に向かない平地以外の環境では使いづらいという問題があ る. 特に段差は市街地等道路が整備された環境であっても至る所に存在し，車いすでの通過を妨げることから， 車いすユーザの移動の自由を制限する要因になっている。これを解消するため，車いすの段差踏破能力をどのよ うに高めるかは関心事項の一つとなっており，研究が重ねられている.

車いすは電動車いすと手動車いすに大別される。それぞれのタイプの車いすで段差踏破を目的とした研究開発 が行われている.電動車いすにおいては, iBOTに代表される階段昇降可能な車いすが開発されている(Kamen et al., 1999) (Morrell et al., 2001). また，Takahashi ら(2003)は縁石などの単一の段差を対象として，倒立振子の要領で車 いすの前輪を持ち上げてバランスをとり，後輪の駆動力を利用して段差を乗り上げる方法を提案している．手動 車いすにおいては，車いす背面に伸縮リンクを取り付け，前輪が段差上にある状態から伸縮リンクを伸ばすこと で車体を段差上に押し上げる方法を森ら(2014)が提案している．また，Munakata ら(2015)は，操舵機能と駆動能 力を持つ電動キャスターとリンク機構, リニアアクチュエータを組み合わせたアタッチメントを手動車いすの背 面に取り付けることで 5 輪構成とし，段差を乗り越える際にはリニアアクチュエータとリンク機構により前輪を 持ち上げ，車いすの後輪と電動キャスターで車体を支える状態とし，電動キャスターの駆動力で段差の上に前輪

No.20-00074 [DOI:10.1299/transjsme.20-00074], J-STAGE Advance Publication date : 28 July, 2020

${ }^{* 1}$ 正員，岐阜県商工労働部産業技術課（干500-8570 岐阜県岐阜市薮田南 2-1-1）

*2 セイコーエプソン (株) (†392-8502 長野県諏訪市大和 3-3-5)

*3 岐阜大学工学部（干501-1193 岐阜県岐阜市柳戸 1-1）

$*_{4}$ 正員, 岐阜大学工学部

E-mail of corresponding author:bando-naoyuki@rd.pref.gifu.jp 
を移動させ，再びリニアアクチュエータとリンク機構により前輪を降ろし，さらに車体を押し上げて段差を踏破 寸る方法を提案している，これらは，車い寸の装置面で機能充実を図り課題を解決しようとするアプローチであ るが，機構が複雑になることから，メンテナンスにコストがかかる，車体が大きく重くなり利便性を損なう，高 価になる，など広く普及するには課題が残されている.

一方，手動車い寸においては，段差踏破をユーザが自ら行う方法もある．これは，駆動輪である後輪を勢いよ く漕ぎ出すことにより, 前輪キャスターを浮かせて後輪のみで車体を支える姿勢とし, バランスを取りながら段 差にアプローチしてキャスターを段差上に降ろし，後輪を力強く漕ぐことで車体を段差上に持ち上げて段差を踏 破する方法で，一連の動作の前半は前輪キャスター上げ動作（以下，キャスター上げ）と呼ばれる.

ユーザはキャスター上げを習得することで手動車いすの持つ利便性を損なうことなく段差踏破が可能となるが， キャスター上げは車体を後方に倒す動作でもあり，そのために後輪を勢いよく漕ぎ出す際，操作を誤ると勢いが 余り後方に転倒し頭部をぶつける危険があることから，キャスター上げの訓練には恐怖や不安が伴うことが指摘 されている(橋本, 2017).

この問題に対し，実際の車い寸を利用して訓練するのではなく, VR 技術によって構築されたシミュレータに よる仮想体験を通じて車い寸の操作感覚を習得する方法が一つの解決策になると考えられる. シミュレータであ れば，後方転倒の危険なく訓練ができる，そこで本研究では，キャスター上げ訓練が可能な車いすシミュレータ の開発を目的とする.

以下，2 章では，車い寸のキャスター上げ動作の運動方程式を立式し，実験により評価する．３章では，この運 動方程式を組み込んだ車い寸シミュレータを構築する. 4 章では, キャスター上げの習得に対するシミュレータ の有効性を評価する．最後に，5章でこれらをまとめる.

\section{2. 運動方程式}

車いすの操作感覚をVR シミュレータで提示するには，仮想空間内における車い寸の振る舞いを決める運動方 程式が必要になる，そこで本章では，車いすのキャスター上げを表す運動方程式を示す．また，実際の車いすで キャスター上げを測定し，シミュレーション結果と比較して，運動方程式の妥当性を評価する.

\section{$2 \cdot 1$ 主な記号}

表 1 に本論文で用いる主な記号を示す。

Table 1 Symbol.

\begin{tabular}{c|l|l}
\hline Symbol & \multicolumn{1}{|c|}{ Definition } & \multicolumn{1}{|c}{ Unit } \\
\hline$m_{c}$ & Mass of body with user & {$[\mathrm{kg}]$} \\
$m_{o}$ & Mass of wheels & {$[\mathrm{kg}]$} \\
$I_{c}$ & Moment of inertia of body with user & {$\left[\mathrm{kg} \cdot \mathrm{m}^{2}\right]$} \\
$I_{o}$ & Moment of inertia of wheels & {$\left[\mathrm{kg} \cdot \mathrm{m}^{2}\right]$} \\
$r_{o}$ & Wheel radius & {$[\mathrm{m}]$} \\
$r_{h}$ & Handrim radius & {$[\mathrm{m}]$} \\
$l$ & Distance of between center of wheel to center of body with & {$[\mathrm{m}]$} \\
& user & \\
$x$ & Moving distance of wheelchair & {$[\mathrm{m}]$} \\
$\theta$ & Body angle of wheelchair & {$[\mathrm{rad}]$} \\
$g$ & Gravity & {$\left[\mathrm{m} / \mathrm{sec}^{2}\right]$} \\
$F$ & Virtual force & {$[\mathrm{N}]$} \\
$F_{h}$ & Control force of wheel with handrim by user & {$[\mathrm{N}]$} \\
\hline
\end{tabular}




\section{$2 \cdot 2$ 立式}

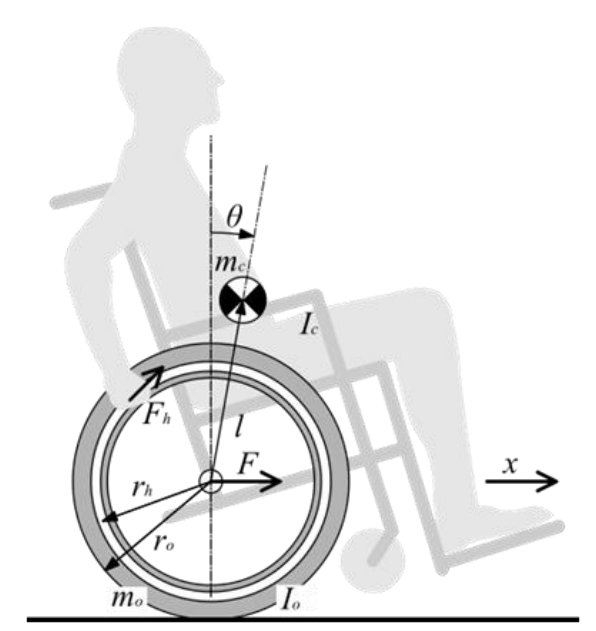

Fig.1 Schematic diagram of wheelie motion by wheelchair.

キャスター上げを行う際，左右の後輪を同じように動かすことを踏まえ，車いすの運動を矢状面上の運動とし て捉えると，車い寸の動きは図 1 のように表すことができる．このときキャスターを宙に浮かせた状態の車い寸 の運動は倒立振子の運動と同じであるため, 運動方程式は以下のように表される.

$$
\begin{aligned}
& \left(m_{c}+m_{0}\right) \ddot{x}+m_{c} l \ddot{\theta} \cos \theta-m_{c} l \dot{\theta}^{2} \sin \theta=F \\
& \left(I_{c}+m_{c} l^{2}\right) \ddot{\theta}+m_{c} l \ddot{x} \cos \theta-m_{c} g l \sin \theta=0 \\
& F=\frac{m_{o} r_{o} r_{h}}{I_{o}} F_{h}
\end{aligned}
$$

ここで, 地面と車輪の間の滑りは考慮していない，また，キャスター上げの操作力に対して小さいため，転が り抵抗は無視している.

上式を用いると, 車い寸ユーザがハンドリムを操作する力 $F_{h}$ から, 車い寸の前後方向の並進加速度艾および後 輪軸まわりの回転角加速度昏を求めることができる.

VR シミュレータにおいては，これらをVR 空間の視点移動，力覚提示用駆動輪の回転および駆動輪軸まわり の車体傾斜に反映させることで, 搭乗者に操作感覚を提示することができる.

\section{$2 \cdot 3$ 評価}

ここでは運動方程式の妥当性を検証するため, キャスター上げを実際の車い寸で行い, 車体の運動を計測した 結果をシミュレーション結果と比較する. 図 2 に, 計測に用いた車い寸（以下，計測用車い寸）の構成を示す. 


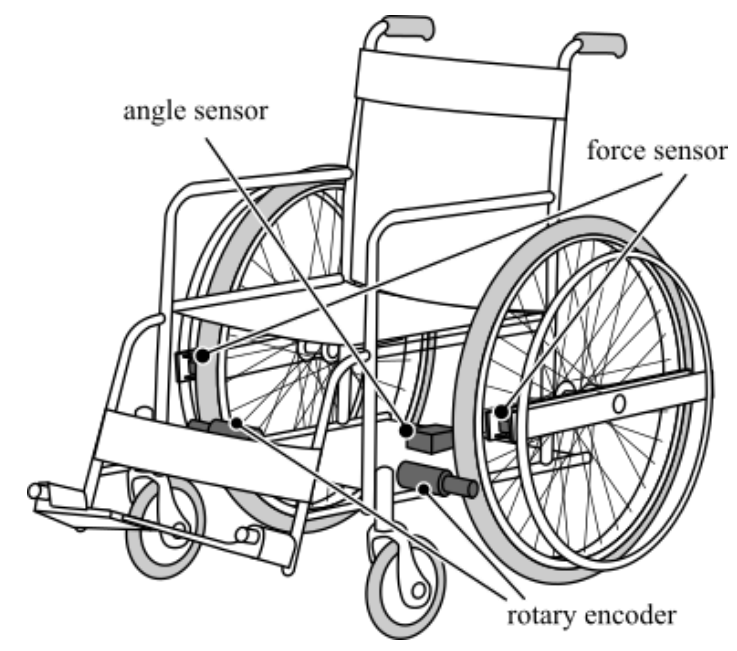

Fig. 2 The wheelchair for measurement.

計測用車いすには，ハンドリムと後輪の間にカセンサ，車体フレームと車輪の間にロータリエンコーダ，車体 フレームに角度センサを設けた。これらにより，ハンドリムの操作力，車体の移動距離，車体の傾斜角度を計測 することができる.

キャスター上げ動作として，キャスターを浮かせた後，一定時間そのままバランスを保った後に前輪を着地さ せる動作を行った際の車いすの移動距離を図 3 に，車い寸の車体傾斜角度を図 4 に示寸．また，これらの計測デ 一タから運動方程式を用いてシミュレーションにより計算した見かけの力と, 計測用車い寸に取り付けた力セン サから換算して得た見かけの力を図 5 に示す，実線が計測結果，破線がシミュレーション結果を表す．なお，本 研究においてはパラメータ設定を容易にするため, 車い寸上のユーザの姿勢は一定と仮定し, 後輪車軸を原点と した車い寸とユーザの重心位置は変化しないものとしている.

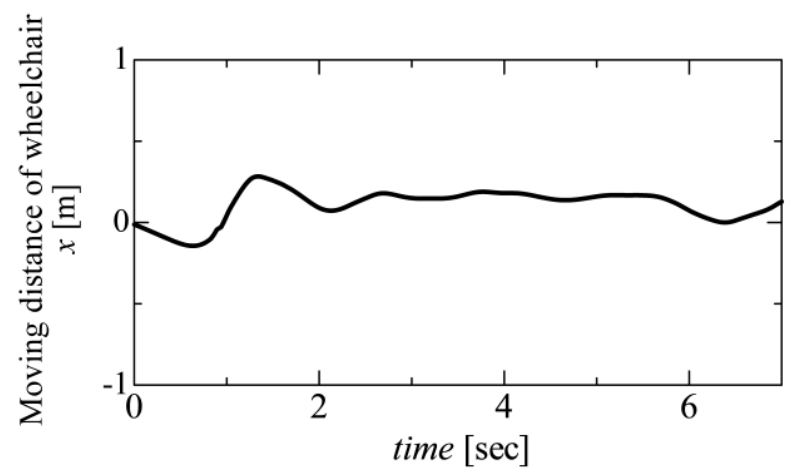

Fig. 3 Moving distance of wheelchair.

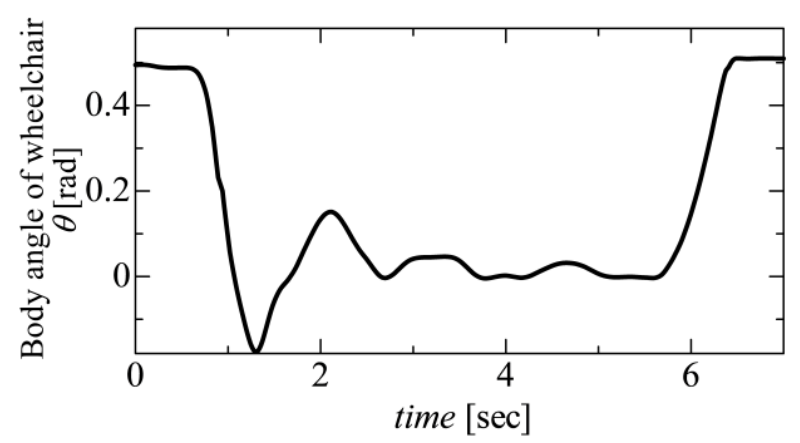

Fig. 4 Body angle of wheelchair. 


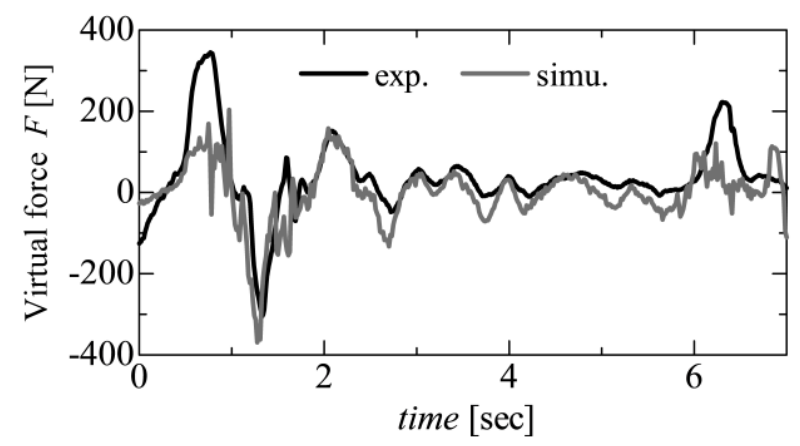

Fig. 5 Comparison of virtual force between experiment and simulation. The virtual force was simulated using the equation of motion from the wheelchair's moving distance and body angle in the wheelie motion measured with the real wheelchair. Further, the data of the force sensor attached to the measurement wheelchair was converted to the virtual force. When they were compared, they almost agreed. Thus, it can be said that the derived equation of motion is valid.

図 5 の実験結果を見ると，操作者は動作開始時に大きな力を加え，その後キャスターが浮いたらバランスを取 るため小さな力で調整している．ここからキャスター上げを習得するには，大きな力で勢いよく漕ぎ，車体の前 進加速度を使って車体重心を後輪軸周りに回転させる感覚と, 行き過ぎた車体の傾斜を調整し, 車体重心が駆動 輪軸上に位置するよう微調整する感覚を覚える必要があるとわかる. 実験結果とシミュレーション結果を比較し てみると, 両者の大まかな特徴は一致している．ここから前節で立式した運動方程式は，キャスター上げを表現 できているといえる.

一方で詳細に見てみると, 実験とシミュレーションの間に多少の差異があることも認められる，これらは，実 験における計測誤差，シミュレーションにおけるパラメータ誤差および運動方程式でモデル化されていない現象 などによるものと考えられる，これらを細かく分析し，実験とシミュレーションを精緻に一致させることは限界 があり難しい。そこでキャスター上げ訓練に，この運動方程式に依る VR シミュレータは有効かを以下で評価す る.

\section{VR シミュレータ}

図 6 は，本研究で構築した車い寸シミュレータ（以下，本システム）の概略図である.

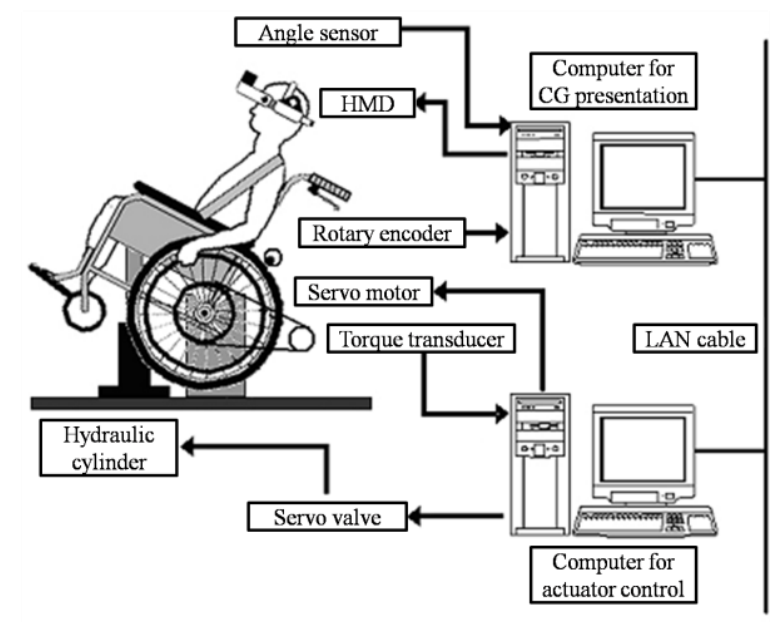

Fig. 6 Schematic diagram of the wheelchair simulator. 


\section{$3 \cdot 1$ 構成}

本システムは車いすの操作感を, 力覚, 車体傾斜感覚および視覚で提示する. 力覚および車体傾斜感覚は, 台 座上に配置された車い寸を介して提示寸る．本システムでは，車い寸を駆動輪が回転できるよう台座から浮かせ た状態で支持している．また，モータによって駆動輪を回すとともに，搭乗者の操作力を計測できるよう，駆動 輪をタイミングベルトおよびトルク変換機を介してサーボモータとつなげている．さらに，駆動輪の回転量を測 定するため, ロータリエンコーダを駆動輪に接するように配置している. 加えて, 駆動輪軸まわりに車い寸を後 傾できるよう，車体と台座の間には油圧シリンダを取り付け，制御用リニアサーボ弁，ポンプユニットおよび制 御用コンピュータによる油圧制御システムを構成している. 車いすの動きは運動方程式によってリアルタイムに シミュレーションされ，コンピュータ内にある仮想空間内で仮想の車い寸が移動する. その際の仮想空間内のユ ーザの目の位置の移動を視覚提示するため, 頭部搭載型ディスプレイ（HMD）を用い，搭乗者の頭部姿勢を測定 するため, HMD には 3 自由度角度センサを取り付けている. なお，本研究では仮想空間の構築を簡略化するた め，仮想空間内のユーザの目の位置は車い寸に対して固定している．ユーザが頭部を回転させて視線方向を変え ることは可能であるが，身をよじるなどのユーザの姿勢変化による目の位置の移動には対応していない，訓練で 用いる段差は仮想空間内にあり CG によってユーザに視認される．ユーザは仮想空間内で仮想の車いすを仮想の 段差に乗り上げる訓練を行う。

\section{$3 \cdot 2$ 仕様}

各種センサにより構成した本システムの分解能は, 搭乗者の操作力が $0.06 \mathrm{~N}$, 頭部姿勢角度が $0.01^{\circ}$, 駆動輪 の回転量が $0.11 \mathrm{~mm}$ である. 車体傾斜感覚を提示するのに用いた油圧シリンダの最大パワーは $67.5 \mathrm{~kW}$, 最大速度 は $400 \mathrm{~mm} / \mathrm{s}$ である. 制御系のサンプリング周期は $10 \mathrm{~Hz}, \mathrm{CG}$ 提示のフレームレートは平均 $18 \mathrm{fps}$ である. なお, 後輪車軸を原点とした車い寸とユーザの重心位置および搭乗者の体重はシミュレータにパラメータとして設定で き，体重は最大 $100 \mathrm{~kg}$ までを想定している．また，仮想空間内の車いすに対するユーザの目の位置や段差の高さ もパラメータとして設定できる.

\section{$3 \cdot 3$ 動作}

本システムの動作は以下のとおりである.

(1) 搭乗者がハンドリムを操作する.

(2) 操作力はトルク変換機を介して制御用コンピュータで読み取られる.

（3）制御用コンピュータは運動方程式を用いてその力に応じた駆動輪の回転速度を算出しサーボモータを 動かす。

（4）サーボモータはタイミングベルトを介して駆動輪に動力を伝え, 駆動輪は回転する.このとき駆動輪は運 動方程式で算出した車体の移動速度に対応した回転速度となるため, 速度変化の大きい動き出しは重く, 速度変化が比較的小さい操作の場合は軽い操作力がハンドリムを握る搭乗者に力覚として伝わる.

（5）また制御用コンピュータは，トルク変換機で計測した操作力から，運動方程式によって算出される車い寸 の傾斜角度となるよう油圧シリンダを伸縮させ，車体傾斜感覚を搭乗者に提示する.

(6) 駆動輪の回転量はロータリエンコーダによって仮想空間提示用コンピュータで読み取られ, その回転量に 応じて車い寸を仮想空間内で移動させる.

（7） 3 自由度角度センサにより搭乗者の視線方向を読み取り，その視線方向の画像を HMD に出力することで 搭乗者に視覚情報を与える.

図 7 に, 車い寸シミュレータの外観を示す. また図 8 に, 車い寸シミュレータの仮想空間画面を示す. 


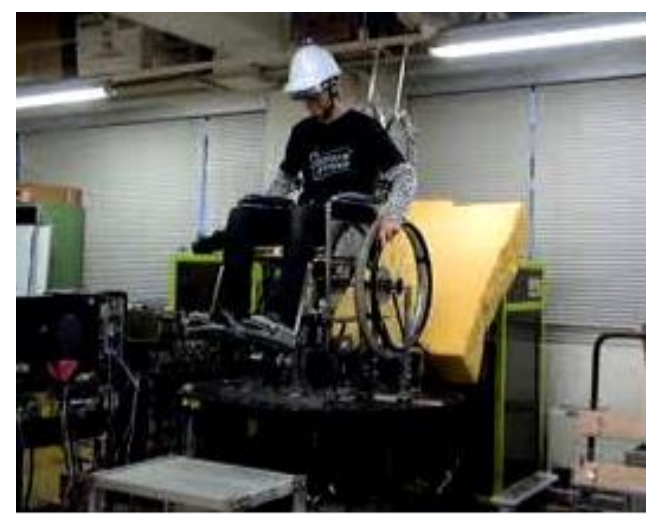

Fig. 7 The wheelchair simulator.
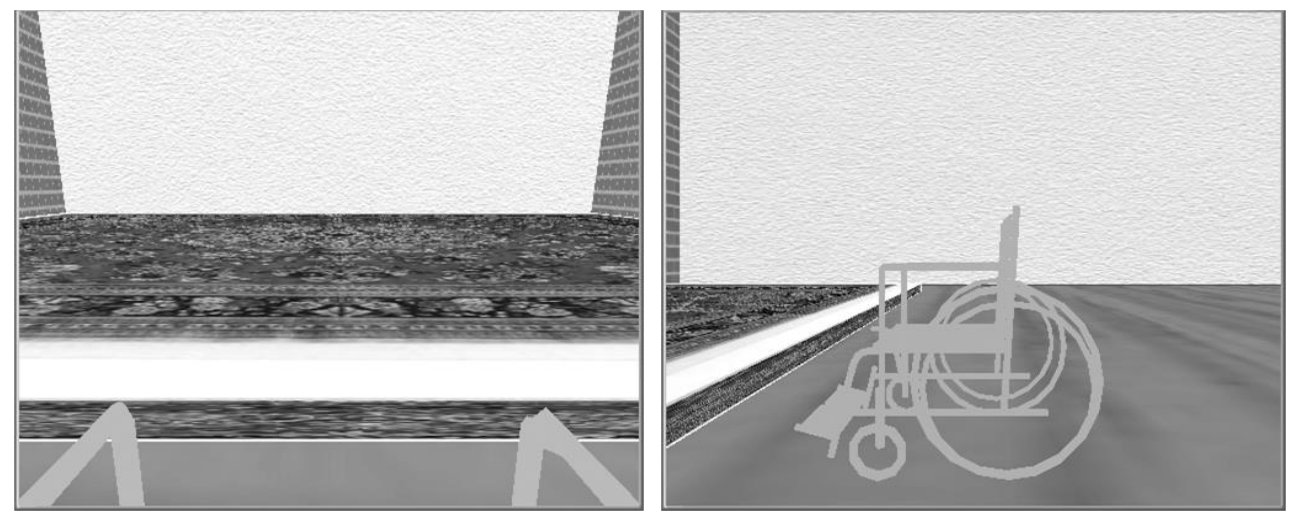

Fig. 8 The screen view of the wheelchair simulator.

\section{4. 評価実験}

\section{$4 \cdot 1$ 実験内容}

本研究で開発した車いすシミュレータを用いてキャスター上げを練習することが，実際の車いすのキャスター 上げの習得に効果を持つか検証するため実験を行った．実験方法を以下に示す.

（1）車いすを使ったことのない健常な男女 20 名を被験者とする.

（2）全被験者に手動車い寸で自由に行動する時間を 5 分与える.この間に前進・後退などの車いすの操作に慣 れてもらう。このときキャスター上げの練習は禁止する.

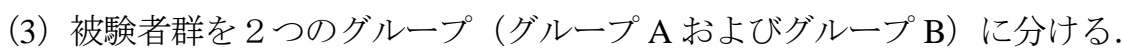

（4）グループ B の被験者には，車い寸シミュレータを使ったキャスター上げの練習時間を 20 分与える．グル ープA の被験者は何もせず，次のステップに進む.

（5）全被験者に実際の車い寸でキャスター上げを試みてもらう。このとき乗り上げる段差は $10 \mathrm{~cm}$ とし，各被 験者には 5 回試行してもらう。また, 成否の判断は, キャスターを段差上に乗せて静止することができた 場合とする. なお，転倒の危険を感じたらすぐに支えられるよう被験者の後ろには実験者が控える.

（6）残したいコメントがあるか，自由回答式で被験者から聞き取る.

\section{4-2 結果}

実験結果を図 9 および図 10 に示す. 図 9 は全試行回数に対する成功回数の割合をグループ毎に示している. 図 10 は横軸に各試行回, 縦軸に各試行回において動作に成功した被験者数の割合を示している.ともに数值が高い 
Bando, Kondo, Ikeda and Yamada, Transactions of the JSME (in Japanese), Vol.86, No.888 (2020)

ほど動作に成功する割合が高いことになる. 図 9 において, エラーバーは標準誤差を表している.グループ A と グループ B の間で $\mathrm{t}$ 検定を行ったところ，有意な差が認められた（t=3.6, $\mathrm{df}=18, \mathrm{p}<.01 ）$.

表 2 には被験者のコメントを示寸.グループ A では実験時の戸惑いが, グループ B ではシミュレータの特徽が 強く印象に残り, これらについてコメントがあった.

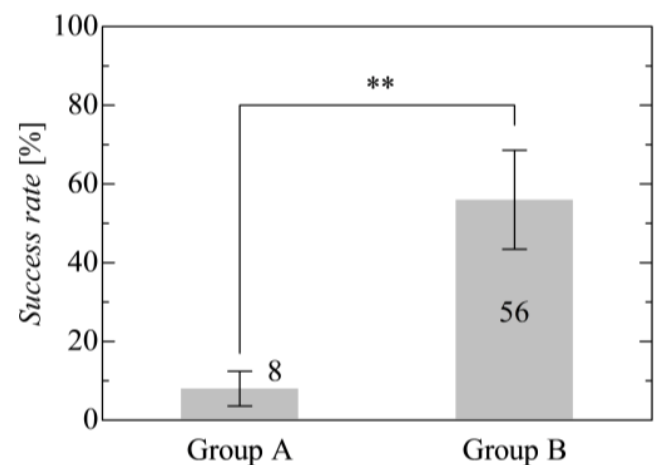

Fig. 9 Success rates of subject groups. A comparison of the success rate of the wheelie operation using an actual wheelchair between the group of subjects trained by the simulator (Group B) and the group of subjects not trained (Group A) showed that Group B had a higher success rate. Thus, it can be said that training with the simulator is effective.

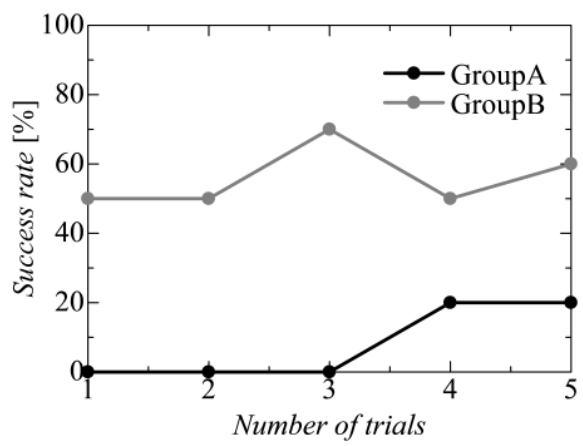

Fig. 10 Success rates of each trials. Group B subjects had a higher success rate from the first try in the test of the wheelie motion with a real wheelchair. This is because they learned the operation by training with the simulator.

Table 2 Comments of test subjects. There was a comment that it was difficult to understand the sense of distance in VR space. From this, there is room for improvement in the visual presentation function in this system.

\begin{tabular}{|c|c|}
\hline Testee & Comment \\
\hline Group & Difficult to get how to lift the front wheel \\
\hline A & Scared to fall back \\
\hline \multirow{4}{*}{$\begin{array}{c}\text { Group } \\
\text { B }\end{array}$} & $\begin{array}{l}\text { It is possible to grasp the tips of movement such as how to } \\
\text { apply power and how to use the body }\end{array}$ \\
\hline & $\begin{array}{l}\text { There is no danger of falling back, so there is a sense of } \\
\text { security in training }\end{array}$ \\
\hline & The sense of distance was difficult to grasp in virtual space \\
\hline & The simulator felt like it was being moved mechanically \\
\hline
\end{tabular}




\section{$4 \cdot 3$ 考察}

図 9 より, 車いすシミュレータを使用したグループ B は未使用のグループ $\mathrm{A}$ に対してキャスター上げの成功率 が高いことがわかる. 平均で比較すると成功率が約 48 ポイント上昇している. 両グループの成功率に差がみられ, 検定の結果から有意差が認められたことから，車いすシミュレータを用いたキャスター上げの練習には効果があ るといえる.

図 10 を見ると，試行回の早い段階において，グループ A の被験者は成功者がゼロであったのに対し，グルー プ B の被験者は半数が成功している。この結果と被験者のコメントから，シミュレータによって被験者はキャス ター上げのコツを覚えることができたといえる.

また，グループ A の被験者から「後ろに倒れていきそうで布かった」というコメントがあったことから，実験 でキャスター上げを試みる際, 勇気を奮い起さなければならなかったことが窺える. 対して, グループ Bの被験 者には同様のコメントがなかったことから, シミュレータは心理的負担の軽減にも効果があったといえる.

以上により，本研究で開発した車いすシミュレータは実際の車いすを用いた訓練での転倒の危険を避け，ユー ザの心理的負担を軽減しつつ，キャスター上げの習得に対し有効な訓練効果が得られることが確認できた.

一方でシミュレータの違和感を訴えるコメントも聞かれた.「シミュレータによって機械的に動かされている感 じがした」というコメントは，感覚提示に用いた機械システムの応答性に起因するものと考えられる．本システ ムでは，力覚，車体傾斜感覚を機械システムによって提示している．しかし，機械システムには応答遅れが含ま れる. そのため, 操作力に対する感覚のフィードバックに遅れが生じ, 搭乗者は動かされているという感じを覚 えたと思われる。これを解消するには，機械システムの速応性を改善する必要があるが，そうすると安定性が損 なわれ，搭乗者を危険にさらす恐れがある.よって，違和感を完全に解消することは難しい．以上のことから， 本システムは感覚提示用の機械システムにおいて，許容できる範囲に違和感を軽減する方針での応答性の調整が 必要といえる.

「仮想空間では距離感覚が掴みにくい」というコメントは，仮想空間内における視点移動の自由度に起因する ものと考えられる. キャスター上げにおいて，車いすと段差の距離を正確に測ることは成功率を高めるうえで重 要である．実際の車いすでキャスター上げを行う被験者を観察すると，キャスターの位置確認と段差との間合い をはかるため，上半身を左右に振りながらキャスターを目視確認している様子が見られた．対して，仮想空間内 における視点位置は車いすに対して固定されている. 搭乗者に許されるのは，HMD に取り付けた 3 自由度角度 センサによる視線方向の変更のみである. こうしたシステム上の制約から，グループ B の被験者は仮想空間内で キャスターと段差の位置関係を把握しないままキャスター上げの訓練をしており，実際の車いすによるキャスタ 一上げでの失敗につながったと考えらえる. 以上のことから，本システムには視覚提示機能に改良の余地が残さ れている.

今後の課題として, 搭乗者が仮想空間内で距離感覚を把握しやすい視覚提示システムの構築がある. これによ り更なる訓練効果の上昇が期待できると考えられる.

\section{5. まとめ}

本研究では，手動車いすユーザの段差踏破技術であるキャスター上げを転倒の危険なく安全に訓練できる VR シミュレータの開発を目的とし, 以下を実施した。

まず, VR シミュレータに必要な運動方程式を立式し, 実際の車いすの運動とシミュレーション結果を比較し た. 次に，この運動方程式を組夕込んだ車いすシミュレータを構築した. そして，キャスター上げの習得に対す

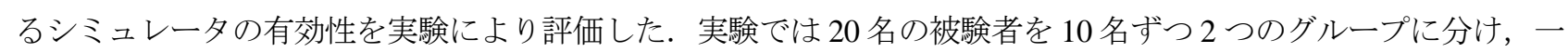
方のグループでは車いすシミュレータを用いて動作の訓練をした後に，もう一方のグループでは動作の練習を行 わないまま，実際の車いすでキャスター上げに試みてもらい，その成功率を集計した，その結果，車いすシミュ レータを使用したグループの平均成功率は，未使用のグループに対して約 48 ポイントの上昇が見られた.

以上の結果より，本研究で開発したシミュレータはキャスター上げ動作の習得に寄与することを示した. 


\section{文献}

橋本大佑,車いすユーザーのための車い寸スキルハンドブック基本編,心力舎 (2017).

Kamen, D. L., Ambrogi, R. R., Duggan, R. J., Heinzman, R. K., Key, B. R., Skoskiewicz, A. and Kristal, P. K., Transportation vehicles and methods, U. S. Patent 5,971.091 (1999).

森善一，勝村薰，永瀬勝也，自走用車椅子使用者のための段差移動補助機の開発，日本機械学会論文集，Vol.80, No.820 (2014), DOI:10.1299/transjsme.2014dr0381.

Morrell, J. B., Kerwin, J. M., Kamen, D. L., Ambrogi, R.R., Duggan, R. J., Heinzman, R. K. and Key, B. R., System and Method for stair climbing in a cluster-wheel vehicle, U. S. Patent 6,311,794 (2001).

Munakata, Y. and Wada, M., Development and analysis of a novel add-on drive mechanism for motorizing a manual wheelchair and its step climbing strategy, Robomech Journal, Vol.2, No.7 (2015).

Takahashi, Y., Ishikawa, N. and Hagiwava T., Soft raising and lowering of front wheels for inverse pendulum control wheel chair robot, Proceedings of the 2003 IEEE/RSJ International Conference on Intelligent Robots and Systems (2003), pp. 3618-3623.

\section{References}

Hashimoto, D.,Skill handbook for wheelchair user basic, Shinryokusha (2017) (in Japanese).

Kamen, D. L., Ambrogi, R. R., Duggan, R. J., Heinzman, R. K., Key, B. R., Skoskiewicz, A. and Kristal, P. K., Transportation vehicles and methods, U. S. Patent 5,971.091 (1999).

Mori, Y., Katsumura, K. and Nagase, K., Development of a pair of step-climbing units for a manual wheelchair user, Transactions of the JSME (in Japanese), Vol.80, No.820 (2014), DOI:10.1299/transjsme.2014dr0381.

Morrell, J. B., Kerwin, J. M., Kamen, D. L., Ambrogi, R.R., Duggan, R. J., Heinzman, R. K. and Key, B. R., System and Method for stair climbing in a cluster-wheel vehicle, U. S. Patent 6,311,794 (2001).

Munakata, Y. and Wada, M., Development and analysis of a novel add-on drive mechanism for motorizing a manual wheelchair and its step climbing strategy, Robomech Journal, Vol.2, No.7 (2015).

Takahashi, Y., Ishikawa, N. and Hagiwava, T., Soft raising and lowering of front wheels for inverse pendulum control wheel chair robot, Proceedings of the 2003 IEEE/RSJ International Conference on Intelligent Robots and Systems (2003), pp. 3618-3623. 